\title{
Strawberry Fruit Yield and Vegetative Growth and Pest Populations in Plantings with and without Cover Crops
}

\author{
Carl H. Shanks, Jr. and Jimmie D. Chamberlain \\ Research and Extension Unit, Washington State University, 1919 N.E. 78th \\ Street, Vancouver, WA 98665-9752 \\ Additional index words. Fragaria xananassa, Tetranychus urticae, Chaetosiphon \\ fragaefolii, spider mites, strawberry aphid, nematodes
}

\begin{abstract}
Totem' strawberries (Fragaria xananassa Duch.) were planted with cleancultivated inter-rows or inter-rows planted with permanent cover crops of white clover (Trifolium repens $\mathbf{L}$.) or 'Manhattan' perennial ryegrass (Lolium perenne L.). There were no significant differences between treatments in the number of twospotted spider mites (Tetranychus urticae Koch), strawberry aphids [Chaetosiphon fragaefolii (Cockerell)], or Pratylenchus sp. or Xiphinema sp. nematodes on strawberry plants. The cover crops reduced strawberry yields relative to cultivation, although fruit size was significantly larger the second year. Root weight did not differ significantly in either year. Weight of above-ground vegetation was significantly higher in cultivated plots the first year, but not the second year.
\end{abstract}

Cover crops or weeds growing among or between the rows of some crops can reduce the number of certain arthropods by encouraging an increase in the number of predatory arthropods (Altieri and Whitcomb, 1979; Altieri et al., 1985; Patriquin et al., 1988; Sanderson and Cutcliff, 1988). However, cover crops sometimes reduce crop growth and yields (Sanderson and Cutcliff, 1988). The objective of this study was to determine whether permanent inter-row cover crops of clover or grass would affect the number of twospotted spider mites or strawberry aphids on strawberry.

\section{Materials and Methods}

'Totem' strawberry plants were planted on 18 Apr. 1990. Plots consisted of ten 7.6-m-long rows spaced $1.1 \mathrm{~m}$ apart with plants set $0.3 \mathrm{~m}$ apart in the rows. Treatments were replicated four times in a randomized complete block design. The planting received $336 \mathrm{~kg}$ of $26 \mathrm{~N}-$

Received for publication 6 July 1993. Accepted for publication 19 July 1993, Research conducted under project no. 1957, College of Agriculture and Home Economics, Washington State Univ., Pullman. The cost of publishing this paper was defrayed in part by the payment of page charges. Under postal regulations, this paper therefore must be hereby marked advertisement solely to indicate this fact.
13P-13K fertilizer and, to control root rots, $2.4 \mathrm{~kg}$ of $N-$ (2,6-dimethylphenyl) $-N$ (methoxyacetyl)alanine methyl ester (metalaxyl) per hectare on 19 Apr. 1990. All rows then were mulched with a 0.3 -m-wide strip of black polyethylene to prevent weeds and covercrop plants from growing into the rows. Runners were not removed, but the plants did not become established due to the plastic.

White clover or 'Manhattan' perennial ryegrass were sown between the strawberry rows on 20 Apr. 1990. The grass was mowed periodically to maintain a $5-$ to 8 -cm height. A third set of plots was clean-cultivated as a control. No insecticides or acaricides were applied during the life of the planting.

Mite counts were determined by picking one mature leaf from each of five plants in the center two rows of each plot. The mites were counted, and the number from the leaves in each plot was pooled. Aphids were counted in the same way, except unfolded, immature leaves were picked.

Plant-parasitic nematode counts were evaluated by taking 10 soil samples that were $1.9 \mathrm{~cm}$ in diameter and $30 \mathrm{~cm}$ deep from within the center two rows of each plot on 10 May 1993. The samples were sent to the Extension Plant Pathology Plant Clinic, Oregon State Univ., Corvallis, for analysis.

Ripe fruit was picked from the center two rows of each plot in 1991 and 1992. Total weight and the weight of 25 fruit were recorded. Also, in June of both years, the eighth and sixteenth plants were dug from rows 4 and 7 or 5 and 8 . Soil was washed from the roots, the vegetative portion was separated from the roots, samples were dried at $\approx 82 \mathrm{C}$, and then weighed. The data were subjected to analysis of variance and Tukey's HSD multiple range test (Analytical Software, 1992).

\section{Results and Discussion}

In 1991 there was a tendency for strawberry plants in the cover-crop plots to have more spider mites and fewer strawberry aphids than those in the cultivated plots (Fig. 1). Mites and aphids were counted only once in 1992, on 4 May. On that date, strawberries in the cultivated, grass, and clover plots averaged 3.0, 10.9, and 4.4 mites and 25.4, 34.9, and 22.1 aphids per leaf, respectively. However, on no dates were the differences significant $(P$ $\leq 0.05)$. We conclude that the cover crops provided no insect control in this test.

The mean counts and standard deviations of Pratylenchus sp. per 0.95 liter of soil for cultivated, grass, and clover were $1268 \pm 413$, $1150 \pm 973$, and $918 \pm 571$, respectively. Xiphinema sp. averaged $1735 \pm 2222,815 \pm$ 1027 , and $770 \pm 1221$, respectively. There were no significant differences between treatments (Pratylenchus, F $=0.26, P=0.78$; Xiphinema, $\mathrm{F}=0.62, P=0.57$ ).

Strawberry plants in the cultivated plot yielded significantly more fruit and were significantly larger in 1991, 1 year after planting (Table 1), than plants grown with a cover crop. Fruit also tended to be larger, but not significantly so. Yields for all plots were much higher in 1992 than in 1991, with no significant differences in total weight of fruit between treatments. Individual fruit from both cover-crop treatments weighed significantly more than those from cultivated plots, but only in 1992. Weights of vegetative growth did not differ significantly in 1992; root weights did not differ significantly in either year.

The overall increase in yields in 1992 may have been due to a milder winter in 1991-92 than in 1990-91. For 7 days in Dec. 1990, temperatures ranged from- 16 to- $12 \mathrm{C}$, unusually cold for Vancouver, Wash. In contrast, Winter 1991-92 was one of the warmest recorded, with temperatures never going below $-4 \mathrm{C}$. It is not clear what caused the plants in the cover-crop plots apparently to have fewer but larger fruit in 1992. Both grass and whiteclover cover crops planted between rows of 


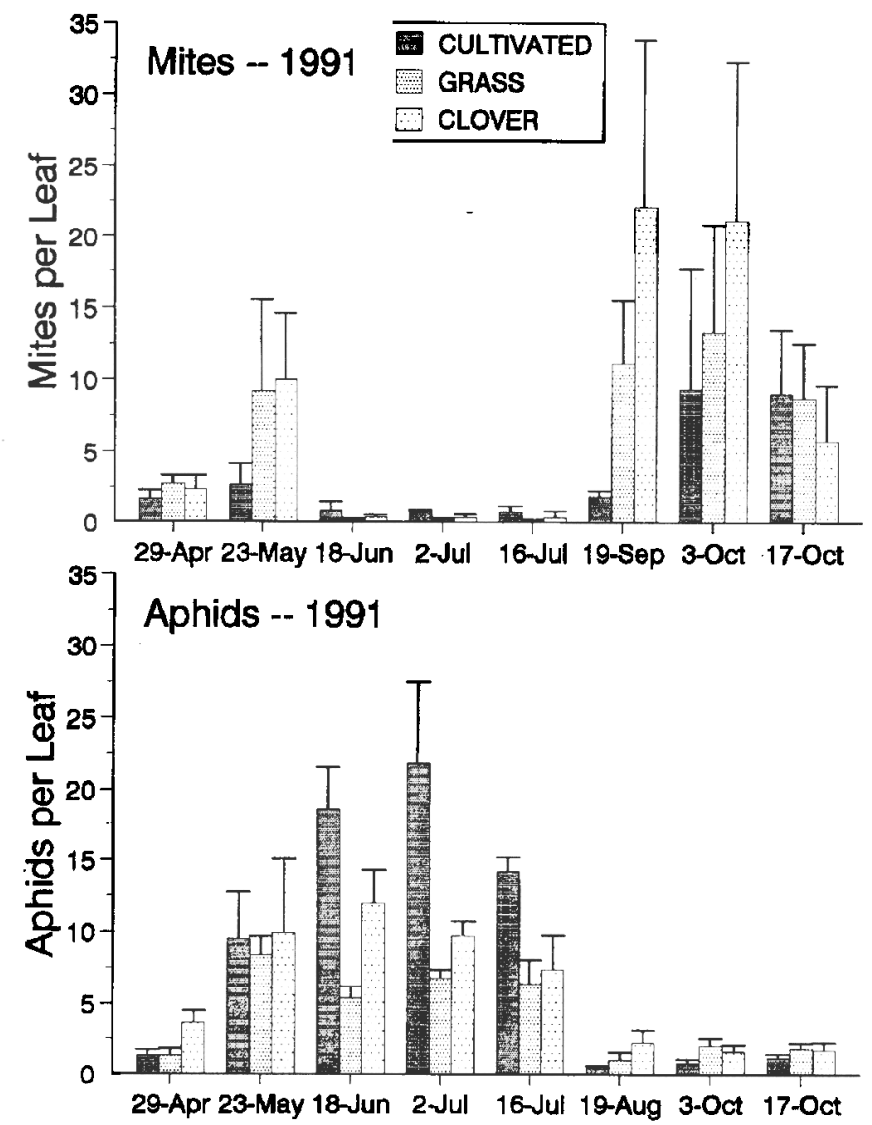

Fig. 1. Number of twospotted spider mites and strawberry aphids on 'Totem' strawberry plants in cultivated plots or plots with grass or clover cover crops.

Table 1. Strawberry yields and plant weight in plantings with and without cover crops, Vancouver, Wash

\begin{tabular}{|c|c|c|c|c|c|c|c|c|}
\hline \multirow{2}{*}{$\begin{array}{l}\text { Cover } \\
\text { crop }\end{array}$} & \multicolumn{2}{|c|}{$\begin{array}{c}\text { Mean wt fruit/ } \\
\text { plot }(\mathrm{kg})^{2}\end{array}$} & \multicolumn{2}{|c|}{$\begin{array}{l}\text { Mean wt } 25 \text { fruit } \\
(\mathrm{g})\end{array}$} & \multicolumn{2}{|c|}{$\begin{array}{l}\text { Mean wt plant tops } \\
\text { (g/plant) }\end{array}$} & \multicolumn{2}{|c|}{$\begin{array}{c}\text { Mean wt roots } \\
\text { (g/plant) }\end{array}$} \\
\hline & $1991^{y}$ & 1992 & 1991 & 1992 & 1991 & 1992 & 1991 & 1992 \\
\hline None & $16.2 \mathrm{a}$ & $33.0 \mathrm{a}$ & $289 a$ & $200 \mathrm{~b}$ & $61.4 \mathrm{a}$ & $64.5 \mathrm{a}$ & $6.5 \mathrm{a}$ & $16.6 \mathrm{a}$ \\
\hline Grass & $7.2 \mathrm{~b}$ & $25.6 \mathrm{a}$ & $251 \mathrm{a}$ & $238 \mathrm{a}$ & $27.8 \mathrm{c}$ & $54.6 \mathrm{a}$ & $3.9 \mathrm{a}$ & $17.1 \mathrm{a}$ \\
\hline Clover & $5.1 \mathrm{~b}$ & $24.0 \mathrm{a}$ & $268 \mathrm{a}$ & $237 \mathrm{a}$ & $47.6 \mathrm{~b}$ & $69.0 \mathrm{a}$ & $5.3 \mathrm{a}$ & $15.3 \mathrm{a}$ \\
\hline
\end{tabular}

${ }^{\text {zPlots were }} 7.6 \mathrm{~m}$ long.

yMeans followed by same letter are not significantly different at $P \leq 0.05$ by Tukey's HSD multiple range test. strawberries appear to be detrimental to fruit production.

Other scientists have observed varied effects of cover crops on strawberries. In Wisconsin, yields were higher with cover crops of 'Regal' perennial ryegrass and wheat(Triticum aestivum L.), but were not affected by Kentucky bluegrass (Pea pratensis L.) (Newenhouse and Dana, 1989). Wheat and rye (Secale cereale L.) did not significantly affect fruit yields in Michigan (Smeda and Putnam, 1988). Early seeded sudangrass [Sorghum sudanense (Piper) Stapf] reduced fruit yields, but when seeded late, it had no effect on yields in New York (Pritts and Kelly, 1992). Whether gramineous plants used as cover crops affect strawberry yields appears to depend on many factors, including time of planting and species.

\section{Literature Cited}

Altieri, M.A. and W.H. Whitcomb. 1979. The potential use of weeds in the manipulation of beneficialinsects.HortScience 14: 12-18.

Altieri,M.A; R.C. Wilson, andL.A. Schmidt. 1985. Theeffectsof living mulches and weed cover on thedynamicsoffoliage-andsoil-arthropodcommunitiesinthree crop systems. Crop Protection 4:201-213.

Analytical Software. 1992. Statistix, version 4.0. Analytical Software, St. Paul, Minn.

Newenhouse, A.C. and M.N. Dana. 1989. Grass living mulch for strawberries. J. Amer. Soc. Hort. Sci. 114:859-862.

Patriquin, D.G., D. Baines, J. Lewis, and A. McDougall. 1988. Aphid infestation of fababeans on an organic farm in relation to weeds, intercrops and added nitrogen. Agr., Ecosystems and Environ. 20:279-288.

Pritts, M.P. and M.J. Kelly. 1992. Alternative weed management strategies for strawberries. Proc. N.Y. State Pest Mgmt. Conf. 55:35-42.

Sanderson, K.R. and J.A. Cutcliffe. 1988. Effect of inter-rowsoil management on growth and yield of red raspberry. Can. J. Plant Sci. 68:283-285.

Smeda, R.J. and A.R. Putnam. 1988. Cover crop suppression of weeds and influence on strawberry yields. HortScience 23:132-134. 